\title{
Winks, Whispers, and Prosecutorial Discretion in Rural Iowa, 1925-1928
}

\author{
EMILY PRIFOGLE
}

IT WAS SUMMER 1920, and Charles Pendleton had just returned to Iowa from Washington, D.C., where for three years he worked for the government during World War I and took law school classes at night at Georgetown University. Pendleton had become a member of the Iowa bar not many days before when he ran into Sherriff Merritt Hoffman in rural Buena Vista County. ${ }^{1}$

"Hey, where you gonta start up be'na lawyer?" asked Sheriff Hoffman.

I appreciate the thoughtful feedback that I received on portions of this article at the Princeton University Modern America Workshop, Brown University Graduate Legal Studies Conference, Indiana University United States History Workshop, and University of Michigan Legal History Workshop, and specifically thank Teal Arcadi, Andrew Edwards, Merle Eisenberg, Don Herzog, Emily Kern, Wangui Muigai, Bill Novak, Eric Sandweiss, Sarah Seo, Daniel Story, and Admiral Weiland for comments that improved the article. Andrew Klumpp offered exceedingly careful and thoughtful editing, for which I thank him. I am also grateful for the generous funding from the State Historical Society of Iowa, the William Nelson Cromwell Foundation, and the Jefferson Scholars Foundation.

1. Charles Pendleton, "Lawyer Sign or Justice is the Best Lawyer, copy \#2" MS146, box 1, Charles Edmund Pendleton Papers, State Historical Society of Iowa, Iowa City (hereafter SHSI), 1-2; Georgetown University, Ye Domesday Booke (Yearbook) (Washington, D.C., 1920).

THE ANNALS OF IOWA 79 (Summer 2020). (C) State Historical Society of Iowa, 2019. 
"At Fort Dodge," replied Pendleton.

"Them Fort Dodge attorneys," by that he meant urban lawyers, "are too smart for a new beginner. They'll eat you up without any salt while you starve to death." Hoffman continued, "Sure Mike, everybody in Storm Lake remembers your seven years as a post office carrier and clerk, and they want you to stay in this county and forget those Washington, D.C. big city airs." ${ }^{2}$

With apparent prompting from a local sheriff, Pendleton began his career in rural Buena Vista County instead of one of Iowa's small cities. Throughout his long career, he retained a primary identity as a small-town lawyer, boasting of the expansive and varied skill set required of small-town lawyers. They were "expected to practice in all courts, government agencies and Washington bureaus and to be informed on all subjects and procedures." By claiming these broad abilities, he also asserted his equality with urban lawyers: "death came and went at my location the same as he did in New York City or any metropolitan center, so do not scorn the small-town attorney, for he deals with life and death, good luck and misfortune, love and hate, taxes and tithes, just like his brothers in big cities." 3

THROUGH CHARLES PENDLETON'S memoirs, this article explores the use of prosecutorial discretion at the ground level in one rural Iowa county in the 1920s. Individuals in rural communities like those where Pendleton was a prosecutor experienced "the law" through distinctly isolated geographies and social networks that lacked anonymity. This lack of anonymity was what scholars of rural America refer to as onymousness- "namedness and knownness" - and it altered patterns of dispute and dispute resolution. Yet as this article makes clear, onymity did not mean homogeneity. Ethnic, racial, and religious diversity created divisions within a community where social distance between individuals was small. Both onymity and diversity shaped who should have access to which types of sanctions and remedies. As the examples in this article demonstrate, some legal transgressions

2. Pendleton, "Lawyer Sign," 1.

3. Pendleton, "Lawyer Sign," 172, 209. 
did not align with transgressions of social norms. In those cases, illustrated most clearly in bootlegging, Pendleton's exercise of discretion (his power to decide independently who to charge with which crimes) adhered closely to the letter of the law. In other cases, legal transgressions did align with social transgressions, but legal processes were not always triggered in response. ${ }^{4}$

The aim of this article, then, is to sort out some of the ways that rural social networks informed prosecutorial acts of discretion in the early twentieth century. To do that, it examines the memoirs of Charles Pendleton, who wrote about his legal practice from his home in Storm Lake, Iowa. Beginning in the 1940s and continuing until the 1970s, he drew on account books, diaries, and letters to recollect his exploits as a lawyer, small-town mayor, and county prosecutor from 1920 through World War II. Pendleton aligned himself with others in his profession who also wrote memoirs, and asserted both his own importance and the importance of his profession to his small rural town. ${ }^{5}$

Legal life writing can play an important role in legal scholarship because neglected voices in the profession, such as rural legal practitioners, can be brought to the fore through autobiography. Self-published and unpublished memoirs, like those of Charles Pendleton, provide one entry point to the understudied rural

4. Colin R. Johnson, Just Queer Folks: Gender and Sexuality in Rural America (Philadelphia, 2013), 21, 110-11, 119; Michael Grossberg, "Institutionalizing Masculinity: The Law as a Masculine Profession," in Meanings for Manhood: Constructions of Masculinity in Victorian America, eds. Mark C. Carnes and Clyde Griffen (Chicago, 1990), 143-45; Robert Wuthnow, "Rural Depopulation," in The Routledge History of Rural America, ed. Pamela Riney-Kehrberg (New York, 2016).

5. Pendleton's son donated six volumes of his father's memoirs to SHSI. Pendleton also self-published one book in 1978 entitled, At the Home Front in War and Life: How a Patriotic Iowa Lawyer Helped Win World War II (Hicksville, NY, 1978). In this article, I make use of two of the memoirs that describe Pendleton's legal practice in the 1920s, and a third that informed my understanding of his practice of writing his memoirs after World War II: Charles Pendleton, "Many War and Living Fronts or Confessions of a Lawyer," MS 146, box 3, Charles Edmund Pendleton Papers, SHSI; Pendleton, "Lawyer Sign;" and Charles Pendleton, "People's Pendleton or Crime Cases, copy \#2," MS146, box 2, Charles Edmund Pendleton Papers, SHSI. Also, one of Pendleton's peers in Storm Lake wrote his own memoir during the same years that Pendleton wrote his memoir. See E.A. Thompson, You Cannot Stand Alone (Mora, MN 1958). 
lawyer. Certainly, Pendleton's status as a white man influenced his belief that his life story was worthy of recording in immense detail; nevertheless, his memoirs provide a "broader version of 'law' and 'society' " by illuminating the entanglement of personal life, community life, and legal life in rural communities. ${ }^{6}$

Pendleton's memoirs are an especially exciting source because they not only offer a particularly candid, if subjective, perspective of a prosecutor but also reflect the onymity that shaped Pendleton's legal practice. The newspapers, legal opinions, census data, and other community members' writings that inform the narratives that follow corroborate portions of Pendleton's memoirs; however, I am relatively unconcerned about the factual truth of the memoirs. This type of source instead offers a subjective truth, but it is precisely Pendleton's subjective perspective that provides insights into the practice of prosecutorial discretion in rural communities. He never tried to conceal the real names of the individuals he described in his stories-they are named, and their namedness mattered to him. ${ }^{7}$

The detailed stories in Pendleton's memoirs enable the examination of rural prosecutorial practice in a period before many legal thinkers had considered the discretionary nature of prosecutors. Prosecutorial discretion generally refers to determinations about whether, when, and how to pursue criminal charges against an individual. These decisions might reflect a sense of fairness or mercy, some utilitarian purpose, or limited enforcement resources. This is an extraordinary power held by prosecutors, and the subject of much recent concern because such

6. For more about the use of memoirs in legal scholarship, see Linda Mulcahy and David Sugarman, "Introduction: Legal Life Writing and Marginalized Subjects and Sources," Journal of Law and Society 42, no. 1 (March 2015), 1; David Sugarman, "From Legal Biography to Legal Life Writing: Broadening Conceptions of Legal History and Socio-legal Scholarship," Journal of Law and Society 42, no. 1 (March 2015), 7-33, 21, 27, 30, 32.

7. As other historians and legal scholars have noted, "there is no way of knowing" if authors accurately reproduce the conversations they include in their memoirs and autobiographies. See Hendrik Hartog, "Abigail Bailey's Coverture: Law in a Married Woman's Consciousness," in Law in Everyday Life, eds. Austin Sarat and Thomas R. Kearns (Ann Arbor, MI, 1993), 68; Sidonie Smith and Julia Watson, Reading Autobiography: A Guide to Interpreting Life Narratives (Minneapolis, 2000), 10-12. 
"discretion is a potential source of societal injustice." In general, this authority is considered to be limited to criminal proceedings, and today "many, if not most, people do not imagine that they may be subject to prosecutorial power." ${ }^{8}$

And yet, at least in Storm Lake, Iowa, in the 1920s, the discretion and authority of the county attorney extended into the lives of "many, if not most, people." Because this discretion in practice was distinct from the twenty-first-century prosecutorial discretion familiar to legal scholars, this article uses the term "county attorney" rather than "prosecutor" and "discretion" rather than "prosecutorial discretion" to reflect the distinct role of the rural prosecutor in the early twentieth century. These words better reflect both Pendleton's self-image as, and his efforts to be, the "People's Pendleton."

Recent research on public prosecutors has called for an emphasis on the importance of place and descriptive analysis of prosecutorial work. To date, historical scholarship on prosecutorial discretion has focused primarily on urban communities. Perhaps this is because some legal scholars have observed a tendency for rural residents to avoid legal remedies for intra-community

8. Peter L. Markowitz, "Prosecutorial Discretion at its Zenith: The Power to Protect Liberty," Boston University Law Review 97 (March 2017), 489-549, 490, 496; David Sklansky, "The Changing Political Landscape for Elected Prosecutors," Ohio State Journal of Criminal Law 14 (2017), 647-74, 669; David Sklansky, "The Problems with Prosecutors," Annual Review of Criminology (2018), 2.4, 2.6; Dwight L. Greene, "Abusive Prosecutors: Gender, Race \& Class Discretion and the Prosecution of Drug-Addicted Mothers," Buffalo Law Review 39 (Fall 1991), 737-802, 741; David Sklansky, "The Nature and Function of Prosecutorial Power," Journal of Criminal Law and Criminology, 106, no. 3 (2017), 474. See generally, Bruce A. Green and Samuel J. Levine, "Disciplinary Reregulation of Prosecutors as a Remedy for Abuses for Prosecutorial Discretion: A Descriptive and Normative Analysis," Ohio State Journal of Criminal Law 14 (Fall 2016), 143-82, 146; Gabrielle M. Thomas, "The Fate of Black Youth in the Criminal Justice System: The Racially Discriminatory Implications of Prosecutorial Discretion and Juvenile Waiver," Rutgers Race \& the Law Review 17 (2016), 267-88; Lissa Griffin and Ellen Yaroshefsky, "Ministers of Justice and Mass Incarceration," Georgetown Journal of Legal Ethics 30 (Spring 2017), 301-35. For a defense of prosecutorial discretion, see William T. Pizzi, "Understanding Prosecutorial Discretion in the United States: The Limits of Comparative Criminal Procedure as an Instrument of Reform," Ohio State Law Journal 54 (1993), 1325-73.

9. Sklansky, "The Problems with Prosecutors," 2.4. 
disputes; however, scholars of rural communities note that a sense of cohesion and shared "common knowledge" among residents has never prevented intra-community disagreement. ${ }^{10}$

Contrary to legal scholar Robert Ellickson's findings that in rural communities "large segments of social life are located and shaped beyond the reach of the law," Pendleton's memoirs reveal that such a conclusion cannot be universally true. Law permeated rural social life and intra-community conflict in Storm Lake. Pendleton's memoirs highlight the fault lines of these rural conflicts and illuminate which groups of community members benefited from selective use of legal action and non-legal resolutions. Pendleton's exercise of discretion reflected the specifics of his rural community, and yet it also mirrored larger themes of all prosecutorial work. ${ }^{11}$

Pendleton was a product of the still fairly recent shift to formal education in (urban) law schools, which embodied a different set of masculine ideals that distinguished well-educated lawyers from the rowdy convivial rural bar. ${ }^{12}$ As one of the few local lawyers with formal legal training, Pendleton ran for county attorney after practicing law for just four years. Between earning admission to the bar in 1920 and his 1924 campaign, he had already

10. Ronald F. Wright and Kay L. Levine, "Place Matters in Prosecution Research," Ohio State Journal of Criminal Law 14 (2017), 675, 678-81, 683-89; Sklansky, "Prosecutorial Power," 473, 475, 478; Carolyn Ramsey, "The Discretionary Power of 'Public' Prosecutors in Historical Perspective," American Criminal Law Review 39, no. 4 (2002), 1309; Allen Steinberg, "From Private Prosecution to Plea Bargaining: Criminal Prosecution, the District Attorney, and American Legal History," Crime and Delinquency 30, no. 4 (1984), 568-92.

11. David Engle, “The Oven Bird's Song: Insiders, Outsiders, and Personal Injuries in an American Community," Law E Society Review 18:4 (1984), 551-82; Carol Greenhouse, Barbara Yngvesson, and David Engle, Law and Community in Three American Towns (Ithaca, NY, 1994); Dorothy Schwieder, Iowa: The Middle Land (Ames, 1996), 161; Robert C. Ellickson, Order without Law: How Neighbors Settle Disputes (Cambridge, MA, 1991), vii, 4.

12. Grossberg, "Institutionalizing Masculinity," 143-45. This article focuses primarily on Pendleton's use of discretion. However, much of that exercise of discretion was an expression of shifting masculine norms in the legal profession in the early twentieth century, which can only be briefly mentioned here. For more analysis of rural masculinity and legal practice in Pendleton's world, see chapter one in Emily Prifogle, "Cows, Cars, and Criminals: The Legal Landscape of the Rural Midwest, 1920-1975," (Ph.D. Diss., Princeton University, 2019). 
served as mayor for two years in Sioux Rapids, Iowa, in northern Buena Vista County. After his successful campaign as a Republican, on January 1, 1925, Pendleton moved to the county seat of Storm Lake to begin his duties as the county attorney for Buena Vista County and gave himself the moniker of the "People's Pendleton." The entire town of Storm Lake, where his office now sat in the courthouse on the square, measured less than a mile between the railroad to the north and lake to the south, and spread out just a smidge over a mile from east to west. The county seat was home to 3,900 community members and was the largest town in the county. ${ }^{13}$

As a rural county attorney, Pendleton's office and position differed from his urban counterparts in a few obvious ways. Small rural criminal dockets reflected smaller rural populations. That often meant that rural county attorneys only served in the role part-time, simultaneously maintaining a private practice or combining criminal prosecution with civil responsibilities (advising the county on issues of contracts, zoning, education, mental health commitments, and so forth). Fewer resources meant minimal, if any, support staff or attorneys to share the load. Further, smaller communities increased the likelihood that a county attorney personally knew the defendants, police officers, judges, counsel, and victims involved in any given case. Perhaps less obvious are some of the implications of those structural differences, which are discussed in the anecdotes that follow. In short, in some ways Pendleton's discretionary power was more expansive than might be expected of a prosecutor, extending beyond the criminal law. At the same time, he addressed legal matters in a relatively informal environment among people who knew each other, and his discretionary power was bounded by community norms around temperance, race, gender, and sexuality. ${ }^{14}$

13. Pendleton, "Lawyer Sign," 403, 434; Pendleton, "People's Pendleton;" State of Iowa, Census of Iowa for the Year 1925 (Des Moines, 1925), 523; Sanborn Map Company, Storm Lake, Iowa [map], 1924, Sheets 1-17 (New York, 1924).

14. For more on the distinctiveness of rural prosecutors, see Frederick B. Bryant, "The Rural Prosecutor," in Public Prosecutors (New York, 1955), 2; Joan E. Jacoby, The American Prosecutor: A Search for Identity (Lexington, KY, 1980), 47-79. 
Pendleton's experience as county attorney demonstrated the scope and limitations of the law to do the work of reconstituting and reinforcing rural norms more broadly. He observed, at least in hindsight, that the small communities surrounding the county seat often preferred to handle "the local problems" without the involvement of the county attorney. While Pendleton was the county's sole legal representative, he was not its only arbiter of conflict. Other leaders in the community, such as mayors, doctors, and even psychics, provided legal advice and social services. ${ }^{15}$

Scholars of rural American communities have found that individual community members often expressed their understanding of social norms by identifying the transgressive behavior of "outsiders" to the community. For example, who brought which legal claims could mark "the social boundaries between [insiders and outsiders]." Social boundaries in a rural community required active safeguarding and maintenance, which included stigmatizing certain types of legal actions brought by certain types of people. Doing so was a way for residents of a community to "exclude from their moral universe what they could not exclude from the physical boundaries of their community." Pendleton's exercise of discretion similarly maintained those social boundaries. ${ }^{16}$

Two powerful forces shaped experiences of insider and outsider status in rural Buena Vista County: onymity and otherness. Anonymity, and its absence (onymity), was a significant influence over perceptions of insider and outsider statuses, and consequently, of Pendleton's discretion. Otherness created along lines of ethnicity, race, and class was also an important influence on community legal norms. Pendleton's memoirs reveal his own liminal status between insider and outsider-someone who had grown up in the county and participated in the community's civic life, but also as someone who had left for better opportunities elsewhere before returning. His memoirs reveal many biases that

15. Pendleton, "People's Pendleton," 106, 164-65, 320.

16. Engel, "Oven Bird's Song," 580-81; Barbara Yngvesson, Virtuous Citizens, Disruptive Subjects: Order and Complaint in a New England Court (New York, 1993). 
purposefully and knowingly influenced his understanding of the community he served and the criminals he prosecuted.

The structure of the close reading that follows reflects the episodic nature of the memoir. Just as Pendleton hopped from one story to the next, the article works through five categories of anecdotes found in the memoirs: race, religion, temperance, gender, and sexuality. Just as Pendleton hoped to use those anecdotes to make an argument for the value of his rural legal practice, I use the anecdotes to argue that in rural communities strong onymous social networks powerfully influenced early twentiethcentury prosecutorial practices. ${ }^{17}$

\section{Race: Insiders \& Outsiders in Rural Iowa}

One troubling example of the intersection of onymity and otherness is Pendleton's account of the "torrid afternoon [that] a group of Mexicans from toothless great grandfather to ... the same kind of baby flooded ... my law offices in the courthouse." He complained of their smell, despite observing that their landlord "made them sleep in an old hog pen." The family approached Pendleton to collect their wages from Jim Little, a tenant farmer, whose land they were working. A young boy translated between the grandfather and Pendleton, telling Pendleton that Little hired them to weed his cornfields, but they now wanted to leave for the beet fields and better housing. As it turned out, Little farmed land

17. Pendleton may be put in conversation with other rural midwestern lawyers across the twentieth century, yet understandable skepticism about whether his memoirs can reveal anything representative or generalizable about rural prosecutors remains. One person cannot stand in for all midwestern rural lawyers or even those in Storm Lake. However, like other rural scholars, I have found across many rural cases that studies of individual rural communities provide generalizable insights into rural law and history. For more about how I consider multiple case studies together, see Prifogle, "Cows, Cars, and Criminals." For examples of how other scholars have found, and proven, that careful close readings of oral histories, memoirs, and novels can provide insights about rural history and the social history of legal practice, see Johnson, Just Queer Folks, 11-12, 111-17; Hendrik Hartog, "The Significance of a Singular Career: Reflections on Daniel Webster's Legal Papers," Wisconsin Law Review (1984), 1105, 1109-10, 1118; and Mary L. Gray, Colin R. Johnson, and Brian J. Gilley, eds., Queering the Countryside: New Frontiers in Rural Queer Studies (New York, 2016). 
owned by Judge James DeLand, who happened to be in chambers at the courthouse when the laborers approached Pendleton. ${ }^{18}$

Pendleton, seemingly thinking the wages were due, "volunteered to take the matter up with [Judge DeLand] feeling he'd order the wages paid." But DeLand insisted otherwise. The contract was indivisible, and the family would not be "entitled to any pay" until they hoed all of the weeds. Pendleton explained to the young boy, "This is the ranchero. He is a great and good Judge and he has ruled that he and his tenant will pay every peso of your agreement to hoe out all the weeds, otherwise they will not pay." After translating Pendleton's words "in Mexican," the young boy flatly stated his grandfather's response: "My grandfather say, 'We poor Mexicans will not hoe another weed on mean American's ranch; they can steal our wages from us but they cannot make us sleep with [sic] their worn out hog house.'" In his memoir, Pendleton simply remarked, "Like a flock of jabbering blackbirds the Mexicans left the center of American justice," and then he moved on to recount a new, unrelated story. ${ }^{19}$

The short account is remarkable. Pendleton did not express surprise at the presence of Mexican migrant laborers in the community or on Little's farm in particular, but instead his account was ambiguous as to his perception of the situation. At first, he told the reader that he thought that the family should receive wages. Pendleton explicitly understood his professional career as dedicated to the underdog, but his understanding of that type of advocacy was complicated by his understanding of race and nationality. Here, he mediated as a favor, but whether the favor was to the migrant workers or DeLand and Little is unclear.

Pendleton did not ask to see a contract, conduct legal research, or take the claim to court because the migrants' complaint was "right" or "just," even though he did when other sympathetic (white) victims in the community approached him for help. Instead, he ostensibly accepted the judge's straightforward application of the entireties doctrine to the labor contract-derived from the legal principles of master-servant relationships

18. Pendleton, "People's Pendleton," 287-88.

19. Pendleton, "People's Pendleton," 288-89. 
stretching back to early nineteenth-century America. The employer was under no obligation to pay even partial wages until the employee completed the agreed upon term of service. Pendleton told the young boy that the judge had "ruled" on their case, but there was no indication of a legal hearing or ruling - the landowner (the judge making the decision) simply asserted he would not pay. Pendleton remarked that the migrant family left the "center of American justice," and only implied, if not ignored, the fact that they left having not actually accessed the justice system at all. ${ }^{20}$

Moreover, Pendleton's proactive efforts to solve this dispute fell outside the scope of his official duties as county attorney. It is possible that the migrant workers approached him in his capacity as a lawyer in private practice, but one gets the sense that the workers went to the courthouse as a site of justice or dispute resolution, not to find the legal offices of an individual lawyer for hire. Pendleton, as county attorney, was someone who could help with a dispute, regardless of whether it involved a criminal act, and apparently even temporary community members like the migrant workers knew to go to him as county attorney to resolve a contract dispute.

Different types of legal actions carry different moral weight in a given community, and recourse to those different legal actions is shaped by community norms. Here, however, it is difficult to find the difference between the outsiders' illegitimate claim for wages due and the legitimate claims of debt collection that Pendleton routinely carried out for prominent white men in his community. In this case, more important than the type of claim being brought was how onymity and otherness intersected to give the final say

20. Pendleton, At the Home Front in War and Life, 263; Pendleton, "Lawyer Sign," 34-35; Christopher Tomlins, Law, Labor, and Ideology in the Early American Republic (Cambridge, 1993), 270, 273-79; "In Iowa," Storm Lake Pilot Tribune, 6/3/1926. See also "Poultry Show at Rembrandt," Storm Lake Pilot Tribune 10/7/1926; "Light Vote Cast at Rembrandt," Storm Lake Pilot Tribune, 6/10/1926; "Rembrandt," Storm Lake Register, 6/10/1926; "Harvesting Beets Near Rembrandt," Storm Lake Register, 10/7/1926; "Rembrandt," Storm Lake Register 12/6/1928; "Market Beets at Rembrandt," Storm Lake Pilot Tribune, 12/6/1928; "Big Acreage of Sugar Beets," Storm Lake Pilot Tribune, 6/17/1926. See also Marc Simon Rodriguez, The Tejano Diaspora: Mexican Americanism of Ethnic Politics in Texas and Wisconsin (Chapel Hill, NC, 2011). 
in the matter to the prominent judge and not the nameless Mexican or Mexican-American outsiders. ${ }^{21}$

The migrant laborers were just one illustration of how even while there was little racial diversity in many small rural towns, the "ideas about race" expressed by rural residents and communities were nevertheless informative of their "view of themselves and their place," insiders and outsiders, and how legal discretion unfolded. Even in acts of kindness to people of color, Pendleton worried that his actions would "giv[e] the Klan an issue" with which to harass him —and unseat him as county attorney. Rural Iowa towns like Storm Lake were not monolithically white, despite census reports indicating that was the case. Race, ethnicity, and religion all informed insider-outsider dynamics and shaped how Pendleton and his community routinely saw and experienced the law. ${ }^{22}$

\section{Religion: Disputes among Insiders}

Pendleton was forced to practice law and navigate community politics at a time when the Ku Klux Klan was on the rise in Iowa.

21. Engel observed that who brought which claims marked "the social boundaries between [insiders and outsiders]." Engel, "Oven Bird's Song," 577, 580-81. He found in his study that in a rural midwestern community in the late 1970s individuals were less inclined to bring personal injury suits against other community members because doing so violated norms about taking personal responsibility for one's actions. In that same community, however, keeping one's word was also valued and corresponded to higher numbers of lawsuits enforcing contracts.

22. Another example of how Pendleton worried about whether an act of kindness to a person of color might raise the ire of the local Klan is found in his story about giving a hitchhiker a ride. Hidden under her sun hat, Pendleton did not realize the woman to whom he was about to give a ride was a black woman. He made a joke of it, and noted for his reader that he dropped her, "that cotton picking baggage," at the edge of town to avoid anyone seeing his act of kindness to a person of color. Pendleton, "People's Pendleton," 190. Thomas J. Morain, "To Whom Much Is Given: The Social Identity of an Iowa Small Town in the Early Twentieth Century," in Iowa History Reader, ed. Marvin Bergman (Iowa City, 1996), 294; U.S. Department of Commerce, Bureau of the Census, Fourteenth Census of the United States Taken in the Year 1920: Volume III Population (Washington, D.C., 1922), 321; U.S. Department of Commerce, Bureau of the Census, Fifteenth Census of the United States: 1930, Population (Washington, D.C., 1932), 756. 
Compared to divisions between insiders and outsiders, the Klan created a divide along political, ethnic, and religious lines within the community and between insiders. Thinking back on his time as county attorney, Pendleton wrote in his memoir, "the Klan became the issue." The Klan tended to be strongest outside of the South in places with very small African American populations, like Buena Vista County. While Pendleton observed that nationally the Klan "was burning niggers at the stakes, whipping trifling white husbands, [and] scaring [sic] foreign born jousting Jews," his detailed accounts of his challenges to the Klan focused almost exclusively on two different issues: temperance and antiCatholic bigotry. Not only were Catholics specifically targeted as feminized or imperfectly masculine traitors to the nation, the Klan tied their anti-Catholicism to violations of Prohibition. Pendleton himself was raised in the Catholic Church-another marker of his sometimes-liminal status between community insider and outsider-but joined a Methodist church once he started practicing law. ${ }^{23}$

The Klan offered rural men several benefits: the chance to join a fraternal organization, the opportunity to have anonymity behind a mask in a community in which there was virtually no anonymity, and an articulation of-and opportunity to performrural manhood. In her study of a rural Klansman from Buena Vista County, historian Dorothy Schwieder observed that at least one local Klan group "accomplished little." Still, the letters of a rural Klansman expressed particular satisfaction in having his identity hidden behind a mask and remarked upon the power of anonymity several times. Klansmen like the ones Schwieder found in Buena Vista County focused on law and order yet encouraged

23. Pendleton, "Lawyer Sign," 347-48, 353-56, 360, 367; Dorothy Schwieder, "A Farmer and the Ku Klux Klan in Northwest Iowa," Annals of Iowa 61 (2002), 286320, 287, 298-300; Linda Gordon, The Second Coming of the KKK: The Ku Klux Klan of the 1920s (New York, 2017), 41-42, 46-47, 96. For more on the Klan in the early twentieth-century Midwest, see Kathleen Blee, Women of the Klan: Racism and Gender in the 1920s (Berkeley, CA, 1991); Shawn Lay, ed., The Invisible Empire in the West: Toward a New Historical Appraisal of the Ku Klux Klan of the 1920s (Urbana, IL, 1992); Leonard J. Moore, Citizen Klansmen: The Ku Klux Klan in Indiana, 1921-1928 (Chapel Hill, NC, 1991). 
actions outside of the law, including raids and burning crosses. Vigilantism expressed the Klan's manliness and pride. ${ }^{24}$

Despite the anonymity of the mask, the Klan controlled much of local politics, and many community members publicly sympathized with their goals. The role of the Klan in informing county sheriffs of bootlegger operations was not insignificant. Thus, Pendleton's responsibilities as county attorney brought him into frequent contact with the Klan. The local Klan rightly understood Pendleton as an adversary because he opposed vigilantism. In a 1925 letter from a local Klansman to his girlfriend, the Klansman observed, "We have a Klan sheriff but our prosecuting attorney is a fish eater and he will do anything he can to fish the Klan." In addition to accusing Pendleton of being a Catholic (a fish eater), the Klan also launched a "propaganda campaign" against Pendleton alleging inappropriate sexual exploits including adultery. Pendleton felt the sting of these assaults on his masculine performance of civic duty, which came from men he thought were uneducated and crass. He emphasized how his handling of cases involving the Klan reflected "the new rural man" of the early twentieth century - in other words, educated, law bound, and respectable. ${ }^{25}$

There are two particularly apt examples from the memoirs that demonstrate how Klan activity and politics influenced Pendleton's discretion. One can be found in "the riots between the Catholics and the Klan over Carney Hall." Tom Carney, a Catholic and owner of a dance hall, rented his space to Lou Wilkie not knowing that it was for a weeklong series of Klan lectures. On Monday night, the first lecture tipped off the Catholics. On Tuesday, the Catholics were quelled only when the police disbanded their gathering outside of the hall. On the advice of lawyers, Carney canceled the lease and locked the doors to prevent a Wednesday night lecture. Then the Klan secured a temporary injunction

24. Schwieder, "A Farmer and the Ku Klux Klan," 228, 314, 319; "Guy Mack Wins for Mayor of Majority of 178," Storm Lake Pilot-Tribune, 4/2/1925; Gordon, The Second Coming of the KKK, 3, 95, 97-98, 107.

25. Schwieder, "A Farmer and the Ku Klux Klan," 228, 307; Pendleton, "People's Pendleton," 43, 299. See Gabriel Rosenberg, The 4-H Harvest: Sexuality and the State in Rural America (Philadelphia, 2015), 58. 
preventing Carney from breaking the contract. "The mud splattered in Carney Hall" on Thursday night. ${ }^{26}$

Pendleton did not learn of this wild dispute until Friday when one of the lawyers involved instructed Pendleton, as county attorney, to deal with the fallout that night. He was tasked with figuring out what to do as the Catholics planned to defend Carney Hall with guns, and the Klan summoned its members to the battle. Pendleton directly brokered a deal. The agreement kept both the Catholics and the Klan away from the dance hall, predicated on Pendleton "personally tak[ing] possession of the building" and threatening to prosecute anyone who showed up for starting a riot. Pendleton's insistence on upholding the Klan's right to free speech upset Catholic residents of Storm Lake. "You uphold their lies," one man charged. "No, indeed," Pendleton replied, but "the way to squelch their propaganda is not by violence." In the end, after an unexciting evening stake-out at the dance hall, Pendleton concluded that "reason had the ninth inning." 27

Another example of how Klan politics influenced Pendleton's prosecutorial work is when a school teacher burned down her schoolhouse. The larger community viewed the crime and investigation through the lens of the Klan-Catholic conflict. The Klan at first believed that a Catholic must have been behind the arson as an act of anti-public school activism. However, the school teacher-a Klan member-had burned down her own schoolhouse to escape her contract. The Klan soon rallied behind her and paid for her attorneys. Although Pendleton prosecuted the school teacher, public sentiment was against him. In a letter written by a local Klansman, the writer expressed certainty among

26. Pendleton, "People's Pendleton," 39-40. The anonymous Klan letter writer from nearby Marathon noted with surprise that "a Catholic in Storm Lake let us have his hall" to host meetings. It is possible that he was referring to this incident, as the timing seems to have coincided with early 1925. If it was the same incident, it is noteworthy that the Storm Lake hall was sought out because antiKlan community members threatened violence if the Klan continued to hold meetings in a movie theater in Rembrandt. Schwieder, "A Farmer and the Ku Klux Klan," 303-04.

27. Pendleton, "People's Pendleton," 40-42. 
his fellow Klansmen that the "Catholics in the community had initiated the investigation." Faced with her confession, her Klansmen supporters helped the teacher explore the possibility of using an insanity-based defense to avoid punishment. In the end she pled guilty in exchange for a suspended sentence. ${ }^{28}$

Often, a conflict that arose in town fell along clear lines between Klan members or Klan supporters and Catholics or antiprohibitionists. Sometimes these divides were explicit-as they were with the Carney Hall dispute, and sometimes they were implicit and only made known through gossip networks-as they were with the case of school arson. Pendleton aimed to solve many of these problems by strictly adhering to legal procedure or appealing to the power of legal action. Perhaps because the community divisions created by the Klan were so dramatic and contentious, Pendleton looked to the justice system as a neutral arbiter that could remove the appearance of his own personal animosity for the Klan from his actions as county attorney. And yet, Pendleton used his discretion to not press any charges in the Carney Hall conflict against either side and chose to leave the legal action in the realm of a contract dispute. Nevertheless, he still acted as a mediator to ease one flare-up in a longstanding and ongoing conflict between Klan members and Catholics.

\section{Temperance: Bootleggers \& Prohibition}

Many community leaders during the four years of Pendleton's tenure as county attorney were Klan members and supporters of Prohibition. While it was Pendleton's responsibility to enforce Prohibition laws, Klansmen in the area-like they did elsewhere in the nation - took it upon themselves to spy on bootleggers and conduct liquor raids. In contrast to this vigilantism, Pendleton believed in controlled enforcement of Prohibition, targeting only those profiting from illegal alcohol sales because "half the male population were experimenting in making home brew beer, bathtub gin, and wild grape wine." Still, similar to a vigilante

28. "Washington Township School Fires Solved," Storm Lake Register, 4/1/1926; Pendleton, "People's Pendleton," 123-27; Schwieder, "A Farmer and the Ku Klux Klan," 315. 
raid, enforcing Prohibition took Pendleton on stake-outs and police raids of stills and bootleggers' operations. ${ }^{29}$

Once, a local resident rushed into Pendleton's office on a Saturday. "I want my farm raided!" announced Henry Tutt, a man Pendleton described as a "retired farmer, brutal landlord, active Methodist and holier than thou prohibitionist." Tutt continued, "I found a ten gallon demijohn full of moonshine hid in a clump of slew grass on my farm." Pendleton suggested that the raid on Tutt's tenant, Charley Brock, wait until Monday. To that, Tutt exasperated, "It will all be sold Saturday night. What do we pay you for?" 30

Pendleton gathered his constable, P.M. Godwin, and a warrant. The two men drove the thirty miles from Storm Lake, just past the small town of Marathon, to the Tutt farm. But it was during the day, and no one was home, so they simply took a look around to find the liquor and then headed to Sioux Rapids for dinner. Once it was dark, the men drove back and parked in a hidden spot about a half mile away. Pendleton recalled, "We proceeded through the corn field to a point where we could keep our sights on the white mule. We squatted tailor fashion on the rich black loam with the green corn stalk making a cathedral of our hiding place. We took turns getting a little shut eye until some excitement would break." Once excitement did break, the two men crawled to a better position, each "wiggling like a snake in the dewy grass." Then, suddenly, "some psychic alarm system caused the booze peddler to loop for his Lizzie." Godwin and Pendleton sprang up and sprinted with excitement. Pendleton was unarmed, but Godwin always carried a couple of guns. As

29. Pendleton, "People's Pendleton," 25. The state laws of Iowa enabled individual citizens to "maintain an action in equity to perpetually enjoin and abate" the liquor nuisance. When such actions were brought by private individuals, the county attorney was required to make "a personal investigation of the place of business sought to be enjoined." In practice, it seems that few Buena Vista County residents brought actual claims in court, but instead simply informed Pendleton to initiate proceedings on behalf of the state. Code of Iowa §919, 96667, 974 (1919); see also Code of Iowa § 1946-2129 (1924). Although ostensibly not required by statute, Pendleton frequently accompanied his officers of the peace during investigations.

30. Pendleton, "People's Pendleton," 277. 
the bootlegger and customer took off in the Ford, the constable yelled, "Halt in the name of the law," but the call went unheeded. Godwin opened fire. ${ }^{31}$

Although the culprits escaped, Pendleton found a complete still and several jugs of whiskey. After officials loaded up the raid's spoils, Charley Brock eventually returned to the farm where he was arrested. Ultimately, Pendleton charged both Charley Brock and his brother Ferris Brock with liquor violations. Ferris pled guilty in an attempt to save his brother. Pendleton observed that "Judge DeLand sentenced him to a three hundred dollar fine and ninety days in jail, which resulted in a six months free ticket of room and board in [jail], for Ferris had no idea of paying any money." While Ferris's plea did not deter Pendleton from prosecuting his brother, it was a successful defense strategy at the trial, where the jury found Charley not guilty. ${ }^{32}$

Most stake-outs and raids took a similar form to Pendleton's Tutt farm raid. Pendleton carefully followed the letter of the law, even if it cost him an arrest. He was not a vigilante like the Klansmen who conducted similar raids. After finding a still on a stakeout, rather than conduct an illegal search, he first went back to town for a warrant when necessary, even if it was the middle of the night, before returning to complete the raid. ${ }^{33}$

Pendleton made sure these raids were reported in the local press. He wanted the community to know about his late-night raids. The Storm Lake Register, for example, published photos of one of Pendleton's victories on the front page. In another frontpage article, the paper credited Pendleton for participating in a raid that involved federal enforcement agents and netted fifteen gallons of alcohol. The article also provided a quotation specifically asserting that Pendleton would be filing charges in court. While his appeal to formal legal processes during bootlegger raids did not differ in intention from his adherence to those processes in other conflicts involving the Klan, Pendleton's appeal to the press was a distinct expression of his discretionary power.

31. Pendleton, "People's Pendleton," 277-79.

32. Pendleton, "People's Pendleton," 280-81.

33. Pendleton, "People's Pendleton," 72-73, 76-78. 
First, he advertised success as part of an ongoing reelection campaign. Second, he modeled rational law enforcement to contrast the Klan's vigilantism, which he hoped to deter. And third, Pendleton was also being transparent about his law enforcement efforts, marking out for the community how Prohibition would be enforced. ${ }^{34}$

The liquor raids are good examples of how Pendleton as prosecutor functioned as a bridge for the community "between law and politics, rules and discretion, courts and police, advocacy and objectivity." While this intermediation is a role with which all prosecutors are tasked both then and now, in this case place mattered for the specifics of how that intermediation unfolded. Pendleton created a bridge between the rule of law in the courtroom and the open country where he and police officers investigated and fought Prohibition crimes. To the liquor still, he brought with him the rule of law by requiring proper procedure like warrants; to the courtroom, he brought with him the experience of having crawled through the mud on a raid. The space of the field invested Pendleton with masculine legitimacy regarding his Prohibition enforcement activities. Thus, he combined two coexisting, perhaps competing, visions of rural masculinity: one in which rural men performed hard physical, often dirty, labor, and one in which rural manhood was increasingly embodied in educated, responsible, and civically engaged community leaders. ${ }^{35}$

34. Pendleton, "People's Pendleton," 79; "Take XG Still Monday Near Rembrandt," Storm Lake Register, 5/7/1925; "Liquor Dive Cleaned Out At Linn Grove," Storm Lake Register, 8/12/1926; "County Officers Raid Lee Township 'Still,'" Storm Lake Register, 8/12/1926; "2 Arrested With 15 Gal. of Alcohol," Storm Lake Register, 10/18/1928; "Sioux Rapids is Peeved Over Raid," Storm Lake Pilot Tribune, 7/30/1925. For more about prosecutors and Prohibition, see Thurman W. Arnold, "Law Enforcement-An Attempt at Social Dissection," Yale Law Journal 42:1 (1932), 1-24, 8-9, 18. Arnold suggested it was the role of the courts, if not the prosecutor, to dramatize "the moral notions of the community." That is precisely what Pendleton did when he sought what Thurman called "the limelight of public observation" with respect to his decisions and actions.

35. Sklansky, "Prosecutorial Power," 503-04, 520. On Pendleton's masculine performance and the legal profession, see Prifogle, "Cows, Cars, and Criminals." On rural masculinity more broadly, see Rosenberg, 4-H Harvest, 58, 64; R. W. Connell and James W. Messerschmidt, "Hegemonic Masculinity: Rethinking the 
But raids were not the only type of Prohibition enforcement, and Pendleton received fees from all types of successful prosecutions of liquor violations. Often prosecutions were the result not of raids but of minor Prohibition infractions: liquor nuisances and drinking and driving. In addition to Pendleton's fees, these prosecutions pulled in fines for the local schools, and the town council specifically charged Pendleton to pursue such fines "that would enrich the school funds instead of prison terms that would cost the taxpayers money." Thus, policing infractions that warranted only fines created multiple community benefits: the appearance of Prohibition enforcement, the ability to continue illicit liquor consumption for those who desired to do so, and revenue for the local school system. ${ }^{36}$

State-based special conviction fees like these were common for legal prohibitions of gambling and liquor precisely because of their unpopularity in some, or maybe most, of a state's communities. They were intended to incentivize public prosecutors like Pendleton to enforce laws that were in tension with local community norms, and in practice forced Pendleton to navigate that tension within his own community. Pendleton's community was divided over the value of Prohibition, and to secure votes, Pendleton as county attorney needed to navigate that divide so that the Klan and prohibitionists thought he was enforcing the law and also so that the drinkers in the community could largely continue imbibing encumbered only by the occasional fine, which acted as a use-tax. It was not just that he was enforcing a law at

Concept," Gender and Society 19, no. 6 (2005), 829-59, 849; Hugh Campbell, Michael Mayerfeld Bell and Margaret Finney, "Masculinity and Rural Life: An Introduction," in Country Boys: Masculinity and Rural Life, eds. Hugh Campbell, Michael Mayerfeld Bell and Margaret Finney (University Park, IL, 2006), 5-6; Linda Lobao, "Gendered Places and Place-Based Gender Identities: Reflections and Refractions," in Country Boys, eds. Campbell, Bell, and Finney, 268. For more about how rural legal practice reflected norms of rural masculinity, see Michael Grossberg, "Institutionalizing Masculinity;" Prifogle, "Cows, Cars, and Criminals."

36. See, for example, 1924 Iowa Code $\S \S 1963,1993,2015$, 2087; Pendleton, "People's Pendleton," 90, 100, 112, 120, 308-09. 
odds with the community's norms; he was enforcing a law, the validity of which was disputed within the community. ${ }^{37}$

Pendleton's annual salary for serving as county attorney was $\$ 1,400$, which was a significant improvement over his private practice. Pendleton explicitly disclaimed any interest in the fees as prosecutorial motivation, but also proudly counted at least $\$ 1,000$ in fees he collected from prosecuting bootleggers. While this conviction-based fee system, for both the schools and Pendleton, served as a profit motive driving discretion in favor of formal legal charges, other factors were also at play. Legal scholar Nicholas Parrillo has suggested that laws created externallylike state Prohibition laws-would not have been experienced by defendants as intra-community conflict because prosecutors like Pendleton received conviction-based fees for enforcement, giving the prosecution effort the character of independent outside intervention. However, in a town as small as Storm Lake, especially at the height of the Klan's power, it would be hard for any defendant to understand criminal prosecution for a liquor violation as anything but a neighbor-to-neighbor dispute- -a dispute among insiders. Thus, the profit motive mattered, but so too did community norms. Indeed, the local Klan's power reveals that the community's lay members continued to hold great sway over the criminal justice system when it came to prosecution of Prohibition violations, and that the need for school funding similarly drove community support for specific forms of enforcement. ${ }^{38}$

The Klan may have criticized Pendleton for not being enthusiastic enough about enforcing Prohibition, but Pendleton knew it was not in the community's interest to charge all bootleggers. In one instance, a community leader made this explicit for Pendleton. When Pendleton sought to convict a doctor of a liquor sale offense, a banker called upon Pendleton "to remember that we

37. Nicholas Parrillo, Against the Profit Motive: The Salary Revolution in American Government, 1780-1940 (New Haven, CT, 2013), 269-72. Court costs that were paid to the attorney were assessed by the court and recoverable contingent on successful prosecution. See Code of Iowa § 1951, 1963, 2023 (1924).

38. Pendleton, "People's Pendleton," 1, 90, 114; Parrillo, Against the Profit Motive, 256, 272-73. 
all lived in the same community and would continue to do so," and urged Pendleton not to seek a jail sentence.

Choices like this one, to look the other way, reflected broader community interests. Fines for Prohibition violations brought funding for county schools and lessened the impact of Prohibition enforcement on bootleggers and their customers. Pleas, mere threats of prosecution, and fines were compromises between divergent community interests, and a reflection of the lack of anonymity in the community. It was not that everyone in Storm Lake knew everyone else. It was that the community's size created social networks that overlapped to such an extent that no one was ever too many steps removed from knowing someone else. A hardship imposed on one individual could have far reaching ripple effects in the community, whether that be the loss of the town doctor's services or money for school coffers. In short, the lack of anonymity mattered for discretion, even when the connections between county attorney, victim, and defendant were not immediate. ${ }^{39}$

\section{Gender: The Prosecutor's Social Welfare Work}

Pendleton often mobilized other community institutions distinct from the legal system to resolve conflict. In his position as county attorney, he said he also "performed all the social welfare work in the county." While "a wave of enlightened sociology had convinced the Board of Supervisors that they should employ a specifically trained social worker," he objected to any deference she tried to command from him, and continued to approach many problems he confronted as county attorney from the perspective of performing social services rather than criminal justice. ${ }^{40}$ The social worker posed a double threat to Pendleton. She infringed upon his power to resolve disputes outside of the criminal justice system, and in the process, challenged the masculine nature of formal community dispute resolution.

In one story involving a case of arson, Pendleton specifically addressed his social work efforts and the threats to his own

39. Pendleton, "People's Pendleton," 258.

40. Pendleton, "People's Pendleton," 127, 151-55. 
power that he perceived to be coming from the woman social worker. Pendleton arrived at the aftermath of a house fire to find the apparent culprit, the elderly Mrs. Trabu, with evidence of arson in her purse: rope, pocket knife, kindling wood, and even the smell of kerosene. When Pendleton questioned the eightytwo-year-old, she defended herself by claiming she was only trying to exterminate bed bugs. The tenants, she said, had refused to pay rent until the bed bugs were gone. Pendleton was not convinced she had not tried to kill the tenants with the fire.

Another man in the room suggested that the social worker be called. This infuriated Pendleton-he was performing the county's social work and did not need a "paid sociologist" to help. He digressed into a mild tirade about the young female social worker's incompetence and lack of knowledge about community resources like the poor farm and home for wayward girls. The young social worker had been openly dissatisfied with, and opposed to, Pendleton's proposed conflict resolutions in the past, and he did not want her to interfere with his handling of the elderly arsonist. In other words, she posed a threat to his discretion to resolve disputes as he saw fit and to the masculinity associated with his being a community leader. ${ }^{41}$

It turned out that no one in the community especially approved of Pendleton charging the old woman with arson and placing her-even for a short while-in the county's very dilapidated jail house. Newspapers from her hometown of Omaha, Nebraska, printed photos of the grandma behind bars. A few weeks later, Pendleton worked out a guilty plea in exchange for parole to one of her sons-in-law. Pendleton thought his agreement to the plea deal was supremely "humane," a quality evidenced by the fact that one of the arsonist's daughters soon afterward kissed Pendleton "on the lips" in appreciation. ${ }^{42}$

As county attorney, Pendleton performed this work-almost always gendered-in other ways as well, such as assisting frequently in the process of making sanity determinations and commitments to the local asylum. One man raved that he needed to

41. Pendleton, "People's Pendleton," 151-53.

42. Pendleton, "People's Pendleton," 154-55. 
be handcuffed to halt the "irresistible impulse" to kill someone. The "insanity committee," composed of the clerk of court, a doctor, and the county attorney, gathered in the clerk's office in the dead of a snowy night to determine that the man should be committed to the nearby "Insane Hospital at Cherokee" until he could be sent permanently to one in Illinois. Pendleton worked to have another man, who was a client of Pendleton's income tax services and who had celebrated New Year's Eve with too much alcohol, "brought before the sanity committee" and admitted to the hospital to avoid being charged with possession of alcohol. In still another case, a distraught doctor called Pendleton to his office, where he confessed to all manner of crimes because he wanted to be convicted and sentenced to death by crucifixion. His prompt admission to the mental hospital was later reversed so that the doctor could resume his practice. ${ }^{43}$

While some community disruptions could be dealt with through commitments to the "insane hospital," others were handled by different institutions. Pendleton, as county attorney, also managed the legal paperwork for the poor farm. He thought nothing of the decision of the poor farm's custodian to send one woman to the state epileptic home. The same man forced her mother to get a hysterectomy and placed the woman's daughter in a school for juvenile delinquents. The woman protested to Pendleton, claiming the custodian was trying to "get even" for her rebuking his passes. She was indignant when Pendleton would not believe her claims of harassment. Another woman "drew a free ticket to the Feeble Minded School at Woodward," after Pendleton failed to secure a conviction for her rape. She testified at the trial that, although she was several months pregnant, she had only had sex once in her life and that it was with the accused just a week prior to the hearing. The justice of the peace dismissed the case for lack of evidence, and she then appeared before the juvenile court. In another instance of a young mother, Pendleton arranged it so that the father-who the girl neither

43. Pendleton, "People's Pendleton," 117, 176, 274-76. For state law regulating the "County Commissioners of Insanity," see Code of Iowa §§ 2054 et. seq. (1919); Code of Iowa §§ 3544 et. seq. (1924). 
wanted to prosecute nor marry-paid for her confinement at the "Florence Crittenden Home for Unwed Mothers." Pendleton boorishly observed that "unpredictable females, and the poor" were issues constantly before him as county attorney. ${ }^{44}$

Taken together, part of Pendleton's job as county attorney extended far beyond being a "prosecutor" of criminal convictions to other realms of community problem solving, like making appropriate use of the county's institutions including the poor farm, the "insane hospital," and homes for the "feeble minded" and "unwed mothers." These institutions served as alternatives to the courtroom for men who experienced psychological or emotional disturbances due to stress or alcohol. Women and children, on the other hand, encountered such institutions with much less power and control. Under Pendleton's oversight, men, with few exceptions, came and went at the "poor farm" and "insane hospital" as it suited their personal interests, like avoiding arrest when caught drinking alcohol. Women, on the other hand, were committed by men, often against their vehemently expressed wishes.

Robert Ellickson's work on the absence of law in rural communities has claimed that "members of a close-knit group develop and maintain norms whose content serves to maximize the aggregate welfare that members obtain in their workaday affairs with one another." Pendleton certainly engaged in welfare maximization when resolving conflict both inside and outside the courtroom, but whose welfare? Ellickson's argument does not sufficiently account for the power of law to shape community norms, nor can Ellickson's work sufficiently account for intracommunity diversity and hierarchies visible through Pendleton's memoirs. Pendleton's discretion was broad in scope. Situated in a small town where community norms significantly influenced

44. Pendleton, "People's Pendleton," 312-13, 315, 191-92. For the law regulating "Guardianship and Custody of Feeble Minded," see Code of Iowa §§ 1952 et. seq. (1919); Code of Iowa $\S \S 3411$ et. seq. (1924): "The county attorney shall, if requested, appear on behalf of any petitioner for the appointment of a guardian or commitment of an alleged feeble-minded person." For the laws governing county poor farms, see Code of Iowa $\S \S 3272$ et seq. (1919); Code of Iowa $\S \S 5297$ et. seq. (1924). 
the execution of the law and were capable of sanctioning transgressors without formal legal recourse, Pendleton had a wide range of options available to him as a county attorney. He had the discretion to not prosecute, craft a favorable plea deal, or ask for a fine rather than a jail sentence. However, his discretion and active participation rarely ended there. He often sought out alternative community institutions to provide sanctions and support for community members who had transgressed social norms or become public burdens even in the absence of a crime. ${ }^{45}$

In this way, he was similar to other local officials in small communities. Pendleton not only sorted "local troubles" from "serious crime," but also he had the power to transform everyday acts into legally recognized acts. His decisions to transform or not transform those everyday acts were bounded by his relationship to individual community members, by his understanding of local hierarchies of ethnicity and gender, and by the law. Pendleton's prosecutorial power and discretion depended on his "mastery of local ways and local knowledge" and "his capacity to translate this skill into a definition of events" in a way that satisfied the individuals involved and recognized the legitimacy of certain claims. Pendleton's decisions about when to use legal measures, institutional supports, or discrete gossip largely turned on the "socially marginalized status" of an individual within a set of established community insiders. Through Pendleton it is possible to see that the moral weight of legal action or inaction was not just determined by insider status, but also by hierarchies among community insiders. In many ways this is not distinct to rural prosecutors. Indeed, the similarities between rural and urban prosecutorial discretion only further work to dispel Ellickson's argument. However, rural norms around race, religion, and gender informed Pendleton's decisions in a community where the social distance between individual residents was small

45. Ellickson, Order without Law, 167. Contrary to Ellickson's assertions, Yngvesson's earlier work demonstrated how courts in small towns worked informally to resolve disputes in ways that enmesh individual disputants in a legal order, even when formal legal sanctions were not invoked. Yngvesson, Virtuous Citizens, Disruptive Subjects, 10-11. 
and non-legal options of sanction and dispute resolution were many, if only available to certain community groups. ${ }^{46}$

\section{Sexuality: Odd Balls}

"Most of the town's odd balls," wrote Pendleton, "were tolerated with a wink in the left eye." Gender studies scholar Colin Johnson has described this common type of response to queer, eccentric, and curious individuals in rural communities as "benevolent toleration." For the people of Storm Lake and other small towns in the 1920s, the term queer did not necessarily mean homosexual, although gay men and lesbians would have fallen under the category. The category, however, referred more broadly to nonconforming people and thus created space for homosexuality in rural communities. Some might expect little room for these "social outliers" in rural communities because of conservative norms or lack of anonymity. However, Johnson has argued that "the same kinds of social entanglements that made it difficult to be a queer in rural and small-town America during the first half of the twentieth century often also made it difficult to brutally sanction or fully police queers in rural and small town America during this period." It was precisely because of the lack of anonymity that rural communities "were able to account for certain individuals' gender and sexual difference," even protecting individual "insiders" from outside criticism. ${ }^{47}$

Understanding this dynamic of benevolent toleration of social outliers in rural communities helps us to interpret one criminal charge that Pendleton discussed at great length in his memoir and to better assess how onymity affected discretion in Storm Lake. This final example demonstrates forcefully the centrality of

46. Yngvesson, Virtuous Citizens, Disruptive Subjects, 7, 10-11, 47; Engel, "Oven Bird's Song," 569. Further, case studies of rural communities, like this one of Pendleton's social and legal world, suggest that today's calls by William Stuntz and others to return to a past of community policing and criminal justice are based on nostalgic tropes that fail to recognize the division and power hierarchies that influence the execution of criminal law even in small communities. See William J. Stuntz, The Collapse of American Criminal Justice (Cambridge, MA, 2011).

47. Pendleton, "Lawyer Sign," 326; Johnson, Just Queer Folks, 21, 108, 110-11, $119,124$. 
winks, whispers, and discretion to dispute resolution in this rural community. One day early in his tenure as county attorney, the chief of police Jack Carey came into Pendleton's office accusing a young white police officer, Elmer Giddle, of being a "c.s.er"cocksucker, a word Pendleton refused to spell out in his memoir. Pendleton was "discreetly reticent" in his response to the allegation of "felatio [sic] sodomy." Pendleton's initial response was both to believe the allegation and also encourage Carey to require Giddle to resign, thereby causing Giddle to leave town. But Carey pressed Pendleton to take action. Giddle was a Klansman, and Carey was Catholic. ${ }^{48}$

A few days later, Carey returned to Pendleton's office with Hank Walsh. Walsh told Pendleton that " 'Nig' Johnson told me that Elmer was a c.s.er." ${ }^{49} \mathrm{He}$ continued on at Pendleton's prompting, "Everyone in town knows that's what he is. Why, the yound [sic] boys follow him around like he was a slut dog." Walsh reported that everyone at the pool hall whispered "c.s.er about him." Carey felt he had proven his case, but Pendleton knew the hearsay - the legal term for gossip and a powerful form of non-legal sanction within the community-would not secure a conviction because Carey was "charging a crime against nature that most citizens will not believe." 50

Pendleton resigned himself to interviewing Doyle "Nig" Johnson:

48. Pendleton, "People's Pendleton," 48. The only other word that Pendleton abbreviated for discreetness in his memoir as often as the word cocksucker is the word pregnant (as p.g.). See for example, Pendleton, "People's Pendleton," 315.

49. "Nig" Johnson's given name was Doyle Johnson. At the time, the census recorded that he was a white teenager living 90 miles away from Storm Lake in Sheldon, Iowa, shining shoes. The Storm Lake community knew Doyle by "Nig." Pendleton wrote his nickname in quotation marks, and seemed uncomfortable speaking out loud the nickname rather than his given name. Still, it is difficult to know what to make of this nickname, and if it was used as a racial slur in some way. Pendleton, "People's Pendleton," 49-50; 1920 U.S. Census, Nokomis, Buena Vista, Iowa; 1925 Iowa Census, Storm Lake Ward 3, Buena Vista, Iowa; South Dakota Department of Health, Pierre, South Dakota, Birth Index, 1856-1917.

50. Pendleton, "People's Pendleton," 49-50, 52. 
"Somebody has to stop him ruining young boys, so I'll spill the beans. Yes, Elber [sic] Giddle is a c.s.er," disclosed Johnson.

"Did he ever commit the act with you?" [Pendleton] demanded.

"Yes, many times."

"Well, why did you permit him?"

"He always had fishing tackle, guns, kodaks, flashlights, and such that he let us play with. Guess we didn't know no better; but that was over three years ago, and you can't do anything to him about it," related "Nig."

Johnson then swore out a statement for Pendleton. Walsh hoped to use the affidavit to send Giddle to jail, but Pendleton knew that the three-year statute of limitations had expired, and so too, apparently, did Johnson. But in his memoir, Pendleton confided to his reader, "Had I the slightest desire to expose Elmer Giddle, I could have summonsed him in for an investigation and quizzing." Clearly, Pendleton continued to think the best course of action was to work discretely to get Giddle removed from the local police force. Rumors started to fly around town shortly after Pendleton's interview of Johnson, and Giddle was suspended from his position as a police officer. For Pendleton, it was all going according to plan. ${ }^{51}$

Giddle confronted a tough choice. According to Pendleton, Giddle stated, "If I skip town as Carey hopes I will, everyone will believe the worst; but if I stay and fight the charge, no one will believe such a heinous accusation. I'm standing pat." Even though loud whispers about Giddle circulated around the small town, new rumors circulated about the ulterior motives of Carey-he only wanted to take down Giddle as a Klansman and political opponent for Carey's position as chief of police. Just two weeks after his suspension, Giddle was back in uniform on the beat. Pendleton stated flatly, "It was the Klan. They ... were the callers of Giddle's dance movements." 52

In fact, the Klan had provided Giddle with enough money to hire some of the county's best attorneys, and apparently the Klan

51. Pendleton, "People's Pendleton," 53-54.

52. Pendleton, "People's Pendleton," 54-55. 
pressured the Sheldon, Iowa, police into forcing Johnson to recant his statement to Pendleton and swear out a second affidavit. Pendleton felt this sting as a personal offense against him. He was "being subjected to a hate Pendleton campaign." The "other county officials shunned me," he protested. It was this personal attack on Pendleton that spurred him to "prove to the satisfaction of everyone that Elmer Giddle is a pervert." 53

With the help of Carey's investigative work, Pendleton found out that a few years before he became county attorney, a man named Paul Zieke, "a regular Y.M.C.A. cutie," led camping trips with the same kids who hung around Giddle. Zieke convinced those boys to make statements against Giddle. At the grand jury hearing, with the "written confessions of sex transgressions" in hand, Pendleton questioned one of the young men who had given a statement to Zieke years before. Upon Pendleton's crossexamination, the young man "hung his head in shame." Then Pendleton called Zieke, who "took charge and gave the jury a masterpiece of a lecture on sex deviation, proving to the entire satisfaction of the grand jury that Elmer Giddle was a corrupter of the male youth of Storm Lake." ${ }^{54}$

The grand jury first sought an indictment against Giddle, and even wanted Johnson to be indicted on perjury charges. But Pendleton reminded the jury and courtroom that the statute of limitations had expired on all known offenses, and everyone in the courtroom seemed acquiesced by Zieke's offer to inform the mayor-elect of what transpired in the secret grand jury proceedings. Yet when the time came to do so, the mayor-elect told both Zieke and Pendleton not to worry because he guaranteed "to keep the boys away from Elmer when he's my Chief of Police." ${ }^{55}$

53. Pendleton, "People's Pendleton," 56.

54. Pendleton, "People's Pendleton," 59, 63, 67-71.

55. Pendleton, with no reference to these events, later recounted Prohibition raids he participated in with Giddle as chief of police. Pendleton, "People's Pendleton," 72, 222. The mayor-elect was an attorney named Guy Mack. Pendleton succeeded Mack as county attorney. Pendleton's memoirs do not cast Mack in a favorable light, calling him "Headachey." Passing references to Mack indicate that he certainly enforced Prohibition and had a "K.K.K. following." The Klan hired him to provide the legal defense for the school teacher who burned down her school house. At the same time, it seems that while mayor, 
While this particular series of events recounted by Pendleton may seem "decidedly singular," "exceptional," unverifiable, or something to be "written off," they bring together threads found in other anecdotes-the importance of the Klan and religious divisions, the power of Giddle's status as both a man and insider of good standing in the community, and the power of winks and whispers both outside of, and within, the formal legal system. The account provides a rare look into how rural communities protected insiders from legal punishment and sought to solve some social transgressions without resorting to the law. We are limited to the perspective Pendleton provided. Newspaper accounts and census data do not help verify the events. However, the community response as told by Pendleton still reveals a great deal about the intersection of sexuality and discretion in this rural community. ${ }^{56}$

First, throughout the entire ordeal most people involved wanted to avoid bringing Giddle to court, and even when Pendleton found the grand jury ready to indict, he told them the statute of limitations prevented the indictment. Neither did anyone ever mention punishing the teens who confessed to engaging in sex acts with Giddle. Indeed, only one young man-Johnsonwas admonished. The social transgression was best sanctioned outside of the courtroom. Community gossip was already at work as one form of non-legal sanction. Giddle's sexuality came to the attention of the county attorney because Johnson had told Walsh that Giddle was a "cocksucker." Pendleton observed twice that the community was "whispering" about Giddle's sexuality. Yet despite, or perhaps because of, this gossip, male teens continued to follow him around.

Scholars have noted the importance of gossip-winks and whispers-as social sanction for community transgressions. However, in order for "truthful negative gossip" to work, the social distance between the subject of gossip and those spreading gossip must be close. The presence of gossip indicates that the

Mack also defended bootleggers as part of his legal practice. Pendleton, "People's Pendleton," 25, 126, 147, 202, 221.

56. Johnson, Just Queer Folks, 113-17. 
community considered Giddle to be an "insider" — someone who was known and recognized when he walked down the street or entered the pool hall. It is hard to know why Johnson told Walsh about Giddle. Gossip seemed to take place in the pool hall, which Giddle reportedly avoided, but also in the wider community. And, Giddle's own remarks indicated that he knew how gossip would function once a charge was brought against him-if he left town, the gossip about his queerness would solidify his outsiderness; if he stayed and faced the charges, the community would likely continue to include him as an insider despite the whispers. ${ }^{57}$

It is also worth noting Giddle's age. When Giddle became chief of police, just as the mayor-elect predicted, the paper observed his young age, 23 . He was the youngest chief of police that the residents of Storm Lake had ever seen. While he was older than the boys who claimed to have engaged in fellatio with him, the age gap was not drastic. The acts were said to have taken place at least three years earlier, when Giddle would have been around twenty years old-the same age Pendleton was when he graduated high school. It is difficult to determine from the vantage point Pendleton provides whether Giddle's act was transgressive primarily because of its same-sex nature, a potential age difference, or both. Johnson did preface his confession by stating that Giddle was "ruining" young boys, which might indicate that the age difference mattered. We cannot know from the perspective that Pendleton provides what the relationship between the teens and Giddle meant to either side-whether the relationship was exploitative or consensual. ${ }^{58}$

Further, Giddle's sexuality seemed to be fairly well known among the young men in the community, several of whom continued to befriend him. But Giddle's homosocial behavior probably did not look out of place on its face to the wider community, and in many respects, it conformed to the community's expectations for young men. He presumably participated in the local Y.M.C.A. by leading camping trips with younger boys, and

57. Ellickson, Order without Law, 57-61; Engel, "Oven Bird's Song," 567-69.

58. "Giddle Youngest Chief of Police," Storm Lake Register, 7/9/1925; "Elmer Giddle is Slated for Chief of Police," Storm Lake Pilot Tribune, 4/2/1925. 
camping was a common expression of rural masculinity rooted in hard work and knowledge of the land. As a police officer, he had "protégés." Most prominent men in his community belonged to fraternal organizations and spent time with other men in similar contexts. Giddle was no different..$^{59}$

The only reason why the county attorney became involved initially, and brought it to a grand jury eventually, was because the Klan supported Giddle, and Carey wanted to get a Klansman fired with ostensibly old gossip. On the one hand, the Klan derided and harassed men who failed to be good husbands. Newspaper coverage of Mrs. Elmer Giddle's social engagements suggests that Giddle did marry soon after he became chief of police. On the other hand, that does not explain why the Klan supported Giddle in the first place. Presumably, he was a dues-paying member, and as a police officer, a valuable member. Perhaps his position as a policeman enforcing Prohibition predisposed him to align with the Klan. Perhaps Giddle sought protection in the Klan. Perhaps his participation in the Klan and law enforcement worked to reinforce the community's perception of him as masculine and thus heterosexual and lessen the perception of the alleged transgressions. We cannot know. ${ }^{60}$

The Klan's support may have enabled him to weather attacks on his sexuality and masculinity and become chief of police in the aftermath of the scandal. Giddle's public reputation, as

59. The Breeze: Storm Lake High School Yearbook (Storm Lake, 1921), 54; Campbell, Bell, and Finney, "Masculinity and Rural Life," 18-19; Jo Little, "Embodiment and Rural Masculinity," in Country Boys, eds. Campbell, Bell, and Finney, 19091. Pendleton himself took his family, and later just his sons, on camping trips each summer. These trips in some way marked his own masculinity, demonstrating his ability to survive in the wilderness with bears and harsh weather. See, for example, Charles Pendleton, "Wild Horse-Radish and Crocuses," MS146, box 3, Charles Edmund Pendleton Papers, SHSI, 218, 290-94, 332. Similarly, Pendleton marked his willingness to get his hands dirty not just in liquor raids but in his own backyard. He maintained his own garden, although he noted that it was beneath a man of his position. Pendleton, "People's Pendleton," 64-66.

60. "Giddle Youngest Chief of Police," Storm Lake Register, 7/9/1925; “Elmer Giddle is Slated for Chief of Police," Storm Lake Pilot Tribune, 4/2/1925; The Breeze: Storm Lake High School Yearbook (Storm Lake, 1921), 54; "Untitled," Storm Lake Register, 7/7/1927; "Society," Storm Lake Pilot Tribune, 6/28/1928. 
recorded in the local paper, appeared untarnished. This should not come as a surprise given work by those like gender studies scholar Katherine Schweighofer who has found that "rural space permits many more variations of queer lifestyles than one might presume." Pendleton's aversion to exposing Giddle and his devotion to the rules of hearsay and the statute of limitations constrained legal proceedings to a private grand jury hearing and kept Giddle from a public trial. This legal process was part of the intended punishment for Giddle. The statute of limitations had expired. Publicly charging Giddle with allegations of sodomy was the rural prosecutor's equivalent to gossip. Such formal and informal allegations could have ruined Giddle's reputation and may have been intended as a means to run him out of town-to transform him into an outsider. His insider status and Klan affiliation, however, offered protection against gossip—formal and informal. Although he was able to remain in Storm Lake and even quickly secured a promotion, the investigation and prosecution likely cost Giddle in significant ways and perhaps limited his ability to continue pursuing homosocial or homosexual relationships. ${ }^{61}$

Pendleton, in contrast, was accused of abusing his power as county attorney to hurl distasteful allegations at a Klan member in the service of an Irish Catholic. During these events, Pendleton presented himself in his memoir as bound by the law and caution as he always did with Klan conflicts. While he certainly distanced himself from, and looked distastefully upon, the behavior of Giddle and the other young men, he did not seem to be threatened by their behavior. The threat to Pendleton's character came, instead, from the Klan's allegations (gossip) that he had been the one who was indiscrete and unlawful. Pendleton included the events in his memoirs for the purpose of showing his stand against the Klan as much as, if not more than, any negative view he had of Giddle's same-sex relationships.

61. Katherine Schweighofer, "Rethinking the Closet: Queer Life in Rural Geographies," in Queering the Countryside, eds. Gray, Johnson and Gilley, 238; Malcolm Feeley, The Process is the Punishment: Handling Cases in a Lower Criminal Court, $2^{\text {nd }}$ ed. (New York, 1992). 
ULTIMATELY, PENDLETON found his time as county attorney far less glamorous than he hoped. His aspirations to use it as a stepping stone to a prosperous law practice or higher political office were dashed when he was roundly defeated in his second reelection contest in 1928. At the same time, Pendleton took pride in his performance as the "People's Pendleton." His opposition to the Klan and (sometimes misguided) kindness given to those in need fueled his pride. He returned to private practice where he worked in Storm Lake as a small-town general practitioner and continued to be a civic leader until his death in the 1970s. ${ }^{62}$

\section{Conclusion}

Just as often as the formal legal system was invoked, so too were winks and whispers. Indeed, the two worked in tandem. The spaces of the law were multiple: the farm, field, still, boarding house, home, school, grandstand, theater, courtroom, law office, and main street storefronts where gossip, onymity, and the law intersected. The law was not only exercised through the physical county courthouse and jail, but also was exercised with legal tools that were utilized as threats (in homes where Pendleton threatened criminal action against delinquent fathers), as limits (in cornfields where the law bounded Pendleton's actions against bootleggers), as gossip (in the grand jury proceedings of Elmer Giddle), as politics (in public speeches and newspaper articles), as revenue (for both Pendleton and local schools), and as entertainment (in theaters, schools, and courtrooms where community members watched trials and hearings for enjoyment).

There is nothing distinctly rural about a prosecutor determining which transgressions deserve legal sanction and which ones do not. That is the job description. In fact, today, advocates of "community prosecution" argue that prosecutors should not be mere case processors but "problem solvers" and "social

62. Pendleton, "Wild Horse-Radish and Crocuses;" Pendleton, "Many War and Living Fronts;" Charles Pendleton, "Poison Draught or Attorney at Mystery," MS 146, box 4, Charles Edmund Pendleton Papers, SHSI; and Pendleton, At the Home Front in War and Life. 
workers." ${ }^{\prime 63}$ Yet Pendleton's efforts to solve problems and act as a social worker were no less embedded with biases. Communities, as David Sklansky succinctly put it, "are complicated places" that, even in their smallest iterations, are not unified in perspective. The rare glimpse into a county attorney's use of discretion that Pendleton's memoirs provide us demonstrates that, if nothing else.

Sklansky has suggested that the "key to understanding prosecutors" might lie in seeing them as mediating figures. That is certainly necessary to understand the rural prosecutor in the early twentieth century. Then, like now, the intermediation role performed by prosecutors was central to the status, importance, and authority of county attorneys like Charles Pendleton. Pendleton's mediation practices were not all that different from the conflict resolution efforts of other community leaders like preachers, mayors, or psychics - each of which solved community problems outside of the realm of formal law. Of course, Pendleton had a tool that those other community leaders did not-near limitless and unilateral power and discretion to turn to legal resolutions. ${ }^{64}$

In rural Iowa, in the 1920s, onymity shaped prosecutorial decisions in distinct ways particularly with respect to Klan influence. Moreover, Pendleton's memoirs dispel any lingering notion that rural communities governed themselves without law and used only other, non-legal systems of conflict resolution. Pendleton's memoirs directly contradict and complicate that claim. Pendleton's actions reveal law enmeshed into everyday acts, spaces, and relationships in the community. Enforcing Prohibition is perhaps the clearest example.

However, Pendleton also used the law as a tool to resolve conflict outside of the formal legal system. The memoirs provide glimpses suggesting that community members routinely turned

63. Sklansky, "The Problems with Prosecutors," 2.14; See Stuntz, The Collapse of American Criminal Justice; Josh Gupta-Kagan, "Rethinking Family-Court Prosecutors: Elected and Agency Prosecutors and Prosecutorial Discretion in Juvenile Delinquency and Child Protection Cases," University of Chicago Law Review 85 (May 2018), 743-824; Worrall, "Prosecution in America," 18.

64. Sklansky, "The Problems with Prosecutors," 2.5, 2.11; Sklansky, "Prosecutorial Power," 477. 
to the county attorney to resolve conflict and other problems. Pendleton described his rural communities as experiencing constant internal conflict. Often, when Pendleton thought the legal system was an inappropriate vehicle with which to solve a problem, he turned to an ad hoc system of social supports, gossip, and institutions while remaining attentive to local status hierarchies. Even when he selected more informal solutions, he chose those solutions in the shadow of legal resolution, which loomed as an ever-present option in the background. ${ }^{65}$

Pendleton, as a rural county attorney in the early twentieth century, did more than exercise discretion within the scope of criminal prosecution, he mediated disputes and performed social work-all in ways that reinforced gendered and racial biases, navigated religious divides, and projected a professionalism and masculinity associated with legal training and rural civic engagement. Discretion was not just about who among the legally guilty deserved legal punishment, but also about who among the social transgressors deserved social sanction, community assistance, or a blind eye.

65. Greenhouse, et. al., Law and Community in Three American Towns; Sally Falk Moore, "Law and Social Change: The Semi-Autonomous Social Field as an Appropriate Subject of Study," Law and Society Review 7, no. 4 (Summer 1973), 71946. 
